\title{
The Study of the Legal Education of Chinese Minority College Students
}

\author{
Deli Sun \\ Minority College \\ Huanghe Science and Technology College \\ Zhengzhou, China
}

\begin{abstract}
The legal education of minority college students, mainly refers to the national college and university education involved in minority college students in order to raise awareness of the law, legal culture thinking, learning legal knowledge education. This study is to inquire and analyze the minority college students' legal education at the present stage, the content of education, principles, measures of important the theoretical significance and practical value on the development of minority legal education. It has the great practical significance and strategic significance in the safeguarding national unity and social stability, promoting national affairs management on the road of the rule of law.
\end{abstract}

\section{Keywords-Chinese Minority College Students; Legal} education; measure

\section{INTRODUCTION}

The minority college students education plays an important part of higher education. Doing good job in training talents of ethnic minorities areas is of great significance to promote the stable and sustainable development, enhancing national unity and safeguard the unity of the country. The minority college students is not only the rule of law education, national education system object of university education but also the transmission of the law legal education,. The study of the minority college students of the new period has important theoretical significance and practical value.

\section{PROBLEMS IN THE LEGAL EdUCATION OF MiNORITY COLLEGE STUDENTS}

\section{A. The Lack of Legal Education and Attention for the College Students}

The main channel of legal education of Minority College Students:

Legal knowledge generally consists of two parts: one is the statute a specific aspects of a field of laws and regulations; two is the principle of knowledge, namely the legal basis of principle theory knowledge. First, the legal education reports for the freshmen education in military training; second, political theory class taught by the politics teacher in class; third, instilling of knowledge with in the annual fire drill; fourth, the legal knowledge of anti-theft fire, human rights mentioned in the college students' safety ,knowledge booklet.

\section{B. The Lack of Targeted Content, Which Focuses on the Form but Ignores Practice}

Textbook covers too broadly, and for the minority students, the content is not detailed and specific, lack of timeliness, which put forward a very high request in legal education teaching in lesson preparation requires the teacher to expend more energy to collect minority related the legal knowledge. The teacher who can truly speak speak through the knowledge of the teacher is less and less.

\section{The Simplification of Legal Education Method}

The legal education of the minority college students bases on the model of traditional class teaching, occasional lecture and class meeting, focusing on the legal theories and knowledge to the students because of the restriction of the school time, class and other aspects. The initiative of the legal practice teaching and students' subjective learning teaching effect is often ignored. At the same time, the school website, radio and so on propaganda of minority college students' education of legal system is less, the school can give students fewer chance to attend law related to the social practice, as there is no lack of among preppy appear petty theft, in violation of the law of the event, students stay at a respectful distance from this kind of students. It did not cause the attention of other students because of the lack by scientific analysis.

\section{Minority College Students' Weak Legal Consciousness}

College students are in the period of the establishment of the outlook on life. Their world outlook, thought is active but is not stable. Most of the students' degree of understanding of the laws and regulations is not enough, for most legal in the state in which a little knowledge such as a "public security management punishment law, " contract law ". They are lack of even basic understanding. The lack of legal knowledge accumulation to a certain extent, led to the implementation of law in the social life of the students suspicion and mistrust. Due to less social practice experience, the college students are lack of the rights of the individual students' concept of the relative. When they meet the situation of their own rights and interests being attacked illegally, the first idea is not to think about use law as a weapon by legal way to maintain their own legitimate interests with lack of the law consciousness. What's more, some of the students even use "an eye for an eye" way to win 
back their so-called "justice", before knowing it is breaking the law. It is also one of the main causes of crime is more and more college students. In addition, in the face of graduation and working pressure, college students focus on their majors, ignoring their legal basic course. Many students just study for the test. This is important factor of weak legal consciousness of the college students.

\section{The Study CONTENT OF LEGAL Education of The CHINA'S ETHNIC MINORITY}

Minority college students' education of legal system, mainly refers to the national minority college students with basic knowledge of law and improve the education of law consciousness. For different professional ethnic minority college students in different cities, it is unrealistic to let them learn comprehensive legal knowledge. We should guide them in learning content and legal knowledge. Teachers must carefully filtrate. After all, school education resources in colleges and universities are not enough. The legal education content of ethnic minority college students does not require much and complete, but should be focused.

\section{A. Improve the Law Consciousness}

To improve the their legal consciousness can cause positive research method, know the law, and strengthen the legal consciousness for minority college students, it is through learning law, understand the relevant laws and regulations, forming the objective consciousness when they face the things, handle various relations in growth. Potential legal consciousness can make students reason to obey the law to achieve the goal of rule of law for a better future. To have the lofty legal faith is the core of the legal system education for minority students.

\section{B. Cultivate the Rule of Lay Thought}

Mode of thinking under the rule of law is defined as: according to the concept of the rule of law, the principle and standard of judgment, people analyze and deal with the problem of rational thinking, forming the habit of thinking, analyzing and solving legal problems with the orientation. How do minority preppie cultivate the rule of law thinking? Minority college students, as a mainstay of the construction of the ethnic minority areas, determine their legal quality which directly affects the process of the rule of law in ethnic minority areas; Behavior, and ethnic minority college students are lack of the rule of law thinking. The rule of law thinking shows the attitude toward law-related issues, underlying the rule of law, is not only a simple research method, ,but also obeying the law and to form the legal belief, the rule of law concepts into a way of thinking. It is the key to the minority preppie legal education.

\section{Have the Knowledge of Law}

Studying law knowledge, students can improve the legal consciousness, cultivate the rule of law thinking and grasp the deep connotation of the law, which can make the ideological and the process of quantitative change to qualitative change. To master the basic theory of marxist jurisprudence, the important point, the basic rules, the legal thought of democracy and legality, can help students understand and practice the party basic strategy of governing the country according to law, be familiar with the specific content and related law laws, problems. When students encountered in the study life, they can take legal weapon, safeguard their rights and interests, and defend the dignity of law.

\section{THE PRINCIPLES OF LEGAL SYSTEM EDUCATION FOR MINORITY STUDENTS}

\section{A. The Principle of "the Pertinence and Effectiveness"}

The fourth plenary session of the party's 18 stressed that to promote the whole society to establish the rule of law consciousness. We should Insist that the dissemination and law-abiding as long-term basic work of governing the country according to law, carry out the rule of law publicity and education, and guide the consciously abide by the law. We will find method and solve the problem by the method... we also should put $t$ he rule of law education into national education system. Pertinence principle is required us to ethnic minorities in the daily education teaching according to the actual situation of preppy and growth environment, to carry out the education of legal system with pertinence. Most ethnic minority preparatory students have strong ethnocentrism, weak independence and, small mind bear ability who are easy to form a circle with national characteristics. During the legal system education for ethnic minorities preppie, teachers should communicate and integrate according to their different stages of ideological dynamic, on the basis of fully respect the national religious practices and beliefs on exchanges, In addition, teachers also need to strengthen legal education according to the student's own family situation, character, the their targeted.

\section{B. The Principle of "the Ideological Problems and Practical Problems}

The reform, development and stability of the ethnic areas in the new historical period are facing new problems. The first is to realize China's dream, minority education of legal system will contribute to positive energy. To realize the great rejuvenation of the Chinese nation China dream, also give minority legal system history mission of higher education work. The second, during the process of building a well-off society in an all-round way, ethnic minority areas exist in developing infrastructure backwardness. There are a series of problems such as the single industry layout, unreasonable institutions and deterioration of ecological environment and so on. Therefore, the legal system education has to achieve the goal to get the expected result, teachers must go deep into the learning life minority preppie, in thinking to do a good job of leading. Thirdly, teachers should grasp the new problems of the new situation, combine with the characteristics of students to solve the problems facing the students thought and meet the needs of minority preppie to deal with the practical difficulties.

\section{The Principle of the Innovation of the Legal System Education for Minority Students}

"Time shift is something different, something different for the same." China is a unified multi-ethnic country. ethnic problem is related to the national unification, consolidating the frontier and ethnic unity, social stability and national 
security, prosperity, reviewing of national work of more than 90 years history, it has eloquently proved that only by constantly innovation ideas, methods to solve the ethnic problems, can we truly achieve the country's stability. For the innovation of the minority college students' education of legal system is imperative. innovation helps to reflect times of ethnic minority college students' education of legal system and enhance the effectiveness. Both the education idea, the innovation of the legal system education thinking, there are forms of education, education contents, education mechanism innovation. We should enhance the permeability of ethnic minority college students' education of legal system for innovation breakthrough and development in innovation the legal system education for minority students in order to build the common spiritual home for the Chinese nation. We should strive to improve the effect of ethnic minority college students' education of legal system in the intended purpose.

\section{The SOlution OF MinORITy COLlege Students' LEGAL SYSTEM EDUCATION}

\section{A. Improve Education workers' Treatment and Their Working Ability}

According to the particularity of minority college students' education of legal system, the college can give appropriate priority to the teachers in such aspects as training, job title and housing. Colleges especially should pay attention to on-the-job training and off-job training of the legal system education workers. Colleges should improve the level and title of degree level, but also on the training content, increase the theory of socialism with Chinese characteristics, the scientific outlook on development and other aspects of knowledge learning. They should pay attention to ethnic minority preparatory ideological and political education of excellent scientific research achievements transformation.

\section{B. Promote Ethnic Minority College Students Comprehensive Quality}

Combining with the characteristics of Minority College students teaching plan formulation, the government can promote the comprehensive qualities of ethnic minority college students, minority college students are poor in basic culture class, which will influence the normal university study life. We should bridge the gap between minority college students in grades. First of all to help minority college students to face the gap in the thoughts, analyze the reason for the poor objectively, find their advantage and build up confidence; second, teachers should adopt the targeted teaching method, strengthen the basic course training and improve the learning ability and comprehensive quality.

\section{Update and Enrich the Content of Ideological and Political Education in the Teaching Practice Constantly}

Full update of ethnic minority college students treat the contents of the education of legal system needs to advance education theoretical basis, to strengthen the Marxism world outlook, the outlook on life, values, view, religion, national outlook of education concept of "six", "four identity" education, which increase form policy lesson with content, strengthen national unity education. The teaching of ideological and political education content should be interspersed with national knowledge, attract the interest of students, deepen the understanding of national history and policy according to the national students emotional and cultural needs.. In the ethnic minority preparatory education teaching promoting national excellent culture, carry forward the national spirit. The national spirit of a nation has distinct national characteristics. We can combine the spirit and National Socialism, communism ideal and faith education, closely with each other, which plays the the positive role of ideological and political education.

\section{Innovate Teaching Mode and Advocate Diverse Teaching Methods}

Legal education workers should learn to better use of network multimedia technology into teaching. In class, making multimedia courseware should be illustrated with students' interest. After school, the legal system education should also use the network platform such as WeChat, QQ, weibo and so on to strengthen communication, exchange and understand the student's thought of dynamic. Diversified teaching methods, we needs to fro change the traditional mode of"a blackboard and a piece of chalk", into the rich and colorful methods in the forefront of the network platform and information storehouse of the legal system education teaching. Innovative teaching mode also should notice to choose the teaching content, and the movie show which is closely related to and the national minority area development, and the country's political and economic trend to make minority college students' classroom teaching more interesting and more vivid, enhancing the effect of the legal system education for minority students.

\section{CONCLUSION}

Minority college students are very valuable human resource.They are the main force of the social economic development in national regions of our country.They safeguard national regional stability and promote the backbone of the national unity and progress. We should adhere to improve the minority students' legal consciousness and cultivate the rule of law thinking with knowledge of the legal system education work, which is both the need of the rule of law, and the important task of safeguarding the national and social stability.

\section{REFERENCE}

[1] Zheng Xuesong. Ethnic minority preparatory education research [D]. Central university for nationalities, 2011

[2] Han Xiaofeng. Minority college students' ideological and political education research [D]. Shanxi normal university, 2011

[3] Zhao. Long College students' ideological and political education under the network environment opportunities challenges and countermeasures research [D]. Shandong university, 2009

[4] Tian Zhongjin.We Chat challenge to ideological and political education and countermeasures research [D]. Jilin university, 2014 